BMJ

Open

Gastroenterology

\section{Effect of season and sunlight on viral kinetics during hepatitis $C$ virus therapy}

To cite: Hernández-Alvarez N, Pascasio Acevedo JM, Quintero $\mathrm{E}$, et al. Effect of season and sunlight on viral kinetics during hepatitis $\mathrm{C}$ virus therapy. BMJ Open Gastro 2017:4:e000115. doi:10.1136/bmjgast-2016000115

- Additional material is available. To view please visit the journal (http://dx.doi.org/ 10.1136/bmjgast-2016000115)

Received 25 July 2016 Revised 28 October 2016 Accepted 28 November 2016

${ }^{1}$ Hospital Universitario de Canarias, La Laguna, Spain ${ }^{2}$ Hospital Virgen del Rocio de Sevilla, IBIS, CIBERehd, Sevilla, Spain

${ }^{3}$ Hospital 12 Octubre, Madrid, Spain

${ }^{4}$ Hospital Universitari i

Politècnic La Fe, CIBERehd,

Valencia, Spain

${ }^{5}$ Hospital Puerta de Hierro,

Majadahonda, Spain

${ }^{6}$ Hospital de Valdecilla,

Santander, Spain

Correspondence to

Dr Manuel Hernández-Guerra; mhernandezguerra@gmail.

com

\section{ABSTRACT}

Background and aims: Rapid viral response (RVR) during antiviral treatment for hepatitis C virus (HCV) predicts sustained viral response (SVR). Recently, vitamin D levels have been associated with SVR. As sunlight is the most important source of vitamin $D$ and shows seasonal variation, we evaluated the effect of season on viral kinetics during peginterferon/ribavirinbased therapy for HCV.

Methods: Consecutive HCV patients treated with peginterferon/ribavirin and boceprevir/ telaprevir (June 2011-July 2014) were included. Patients were grouped according to season when therapy was initiated (Season A: May-October and Season B: November-April) depending on hours of daily sunlight. Multiple logistic regression analysis included factors known to influence SVR to treatment. The dependent variables were undetectable viral load (VL) or VL $\leq 15 \mathrm{Ul} / \mathrm{mL}(\mathrm{VL} \leq 15)$ at weeks 4,8 and 12, end of treatment and SVR.

Results: The study included 930 patients $(66.8 \%$ men; median 54 years) treated with telaprevir $(n=537)$ or boceprevir, without $(n=481)$ or with lead-in therapy of peginterferon/ribavirin. Baseline characteristics of patients in Season A (45.3\%, $n=421)$ and Season B groups were similar. Overall, a higher rate of RVR (23.5\% vs $16.1 \%, p=0.005)$ and $\mathrm{VL} \leq 15(51.0 \%$ vs $38.6 \%, p \leq 0.001$ ) was observed in patients starting treatment during Season A versus Season B. By logistic regression analysis, initiating treatment in Season $A$ proved to be an independent predictor of RVR and VL $\leq 15$.

Conclusions: In our setting, seasonality affects viral kinetics in HCV genotype 1 patients treated with peginterferon/ribavirin-based therapy. Our findings support the hypothesis that vitamin $D$ influences viral response to peginterferon/ribavirin-based therapy.

\section{INTRODUCTION}

Vitamin D is known to play a key role in calcium and bone homeostasis, but there is emerging evidence that it also has antifibrotic and anti-inflammatory properties. ${ }^{1}{ }^{2}$ In fact, latest studies have found an association
Summary box

This is the first study to establish a link between the season of initiating interferon/ribavirin-based therapy for chronic hepatitis $\mathrm{C}$ and viral response to treatment.

- Patients starting treatment during the season with the highest daily hours of sunlight showed the highest rate of rapid viral response.

- Our results suggest that viral response to treatment is influenced by the hours of sunlight, and by inference, sunlight exposure, a surrogate marker of vitamin D levels.

- Our findings support the hypothesis that vitamin D influences the viral response to peginterferon/ ribavirin-based therapy.

between low vitamin $\mathrm{D}$ levels and risk of severe chronic hepatitis $\mathrm{C}$ (CHC) and cirrhosis, ${ }^{3-5}$ suggesting that vitamin $\mathrm{D}$ deficiency may be involved in the progression of chronic liver disease. ${ }^{6} 7$ In addition, vitamin $\mathrm{D}$ has immunomodulatory properties and in vitro experiments have shown that cholecalciferol has antihepatitis $\mathrm{C}$ virus (HCV) effects, which may theoretically improve response to antiviral therapy in patients with CHC. ${ }^{8}$ More recently, vitamin $\mathrm{D}$ has been shown to reduce anaemia induced by ribavirin avoiding dose reduction. ${ }^{9}$ Finally, recent studies have shown that vitamin D levels correlate with viral response to treatment. ${ }^{3}$ 10-12 However, some investigators have not corroborated these findings; ${ }^{7}$ the discrepancy of results has been mainly attributed to methodological limitations and bias, and thus more evidence is needed on this issue.

During recent decades, $\mathrm{CHC}$ has been treated with regimens based on interferon, with variable effectiveness. This variability depends on viral and host-related factors which affect the likelihood of achieving a rapid viral response (RVR), defined as 
undetectable viral load (VL) after 4 weeks of treatment. RVR, in turn, predicts sustained viral response (SVR), defined as undetectable VL 24 weeks after the end of treatment. ${ }^{11} 13$ The search for new factors able to predict treatment response has been a constant during the therapeutic peginterferon/ribavirin era. Current evidence shows that IL-28B polymorphism, genotype, degree of hepatic fibrosis and baseline VL, among others, are solid independent factors associated with RVR and SVR. ${ }^{11} 121415$

Given that the major source of vitamin D is exposure to natural sunlight, and that sun-induced vitamin D synthesis is greatly influenced by season, ${ }^{1}{ }^{16}$ our aim was to evaluate the effect of season on viral kinetics with peginterferon/ribavirin-based therapy for CHC.

\section{PATIENTS AND METHODS}

\section{Patients}

Patient data were obtained from a prospective multicentre registry promoted by the Spanish Association for the Study of the Liver (HepatiC Registry database). The present study included consecutive HCV genotype 1 patients attending the participating centres and treated between June 2011 and July 2014 with peginterferon/ ribavirin and telaprevir or boceprevir. Patients were recruited from different geographical areas and classified accordingly: Northern, Central and Southern Spain.

The month of initiating therapy was obtained from the database and patients were grouped into Season A (from May to October) and Season B (from November to April), that is, the months with higher and lower hours of sunlight during 2012 according to the Spanish Meteorological Agency records ${ }^{17}$ (figure 1). In addition, to evaluate the effect of initiating treatment during the months with the highest versus the lowest daily hours of sunlight, intermediate months were excluded and patients were grouped into Season $\mathrm{A}^{\prime}$ (from July to September) and Season B' (from January to March).

Patients were also grouped according to the type of treatment, that is, with or without peginterferon/ribavirin lead-in therapy.

\section{Clinical and laboratory data}

Demographic, anthropometric and clinical data were collected for all patients. Body mass index was calculated based on weight in kilograms and height in metres. A cut-off body mass index of $30 \mathrm{~kg} / \mathrm{m}^{2}$ was used to group patients. Degree of fibrosis was assessed by liver biopsy (Metavir score) or ultrasound elastography when available. IL28B polymorphism (CG vs other result) and HCV genotype 1 subtype (1a, $1 \mathrm{~b}$ or indeterminate) were determined. Previous treatments were also recorded and patients were categorised as naive or experienced (no response, early discontinuation, unknown response, relapse, partial response and breakthrough). A cut-off baseline VL of $600000 \mathrm{UI} / \mathrm{mL}$ was used to distinguish high from low VL. ${ }^{14} 18$
HCV viraemia (quantitative, qualitative and log RNA) was recorded at baseline and during treatment at weeks $4,8,12$; at the end of treatment and 24 weeks after treatment completion. Viral responses were evaluated at different time points, and RVR defined as undetectable HCV RNA at 4 weeks and SVR defined as HCV RNA indetectability more than 24 weeks after treatment completion. We also recorded cases with $\mathrm{VL} \leq 15 \mathrm{UI} / \mathrm{mL}$ (VL $\leq 15)$ measured at week 4 .

\section{Vitamin D levels}

Blood samples drawn at the start of treatment were only available from a single centre in the Northern area and were used to evaluate vitamin D levels, determined by electrochemiluminescence. Values are expressed in $\mathrm{nmol} / \mathrm{L}$.

\section{Ethics statement}

Approval for the study protocol was obtained from the promoter's research ethics committee and written informed consent was obtained from all participants. The study was conducted in accordance with the principles of the 1975 Declaration of Helsinki.

\section{Statistics}

Categorical variables are expressed as frequencies and percentages. Continuous variables are expressed as means and SDs.

The assumption of normality was tested with the Kolgomorov-Smirnov test. Comparisons of continuous variables between groups were carried out with Wilcoxon-Mann-Whitney test. We used $\chi^{2}$ or Fisher exact tests to compare proportions, as appropriate.

Two multiple logistic regression models were constructed. The dependent variable was RVR in the first model and VL $\leq 15$ in the second. In both models, season of treatment initiation was the main independent variable, controlling for VL, genotype 1 subtype, IL-28B status, degree of fibrosis, age, type of treatment, presence of diabetes and previous treatment response. The logistic regression results are expressed as ORs and 95\% CIs.

Statistical analysis was performed using SPSS program V.15.0 for Windows (SPSS, Chicago, Illinois, USA). All $\mathrm{p}$ values lower than 0.05 were considered statistically significant.

\section{RESULTS}

\section{Characteristics of the study groups}

The study included 930 consecutive patients $(66.8 \%$ men; median age 54 years, range $15-81$ years) treated for HCV with at least 4 weeks of follow-up. Regarding treatment initiation, $45.3 \%$ of patients $(n=421)$ started peginterferon/ribavirin-based therapeutic regimen during Season A and 54.7\% ( $\mathrm{n}=509)$ during Season B. Table 1 shows their baseline demographic, clinical and analytical characteristics. Regarding the main 


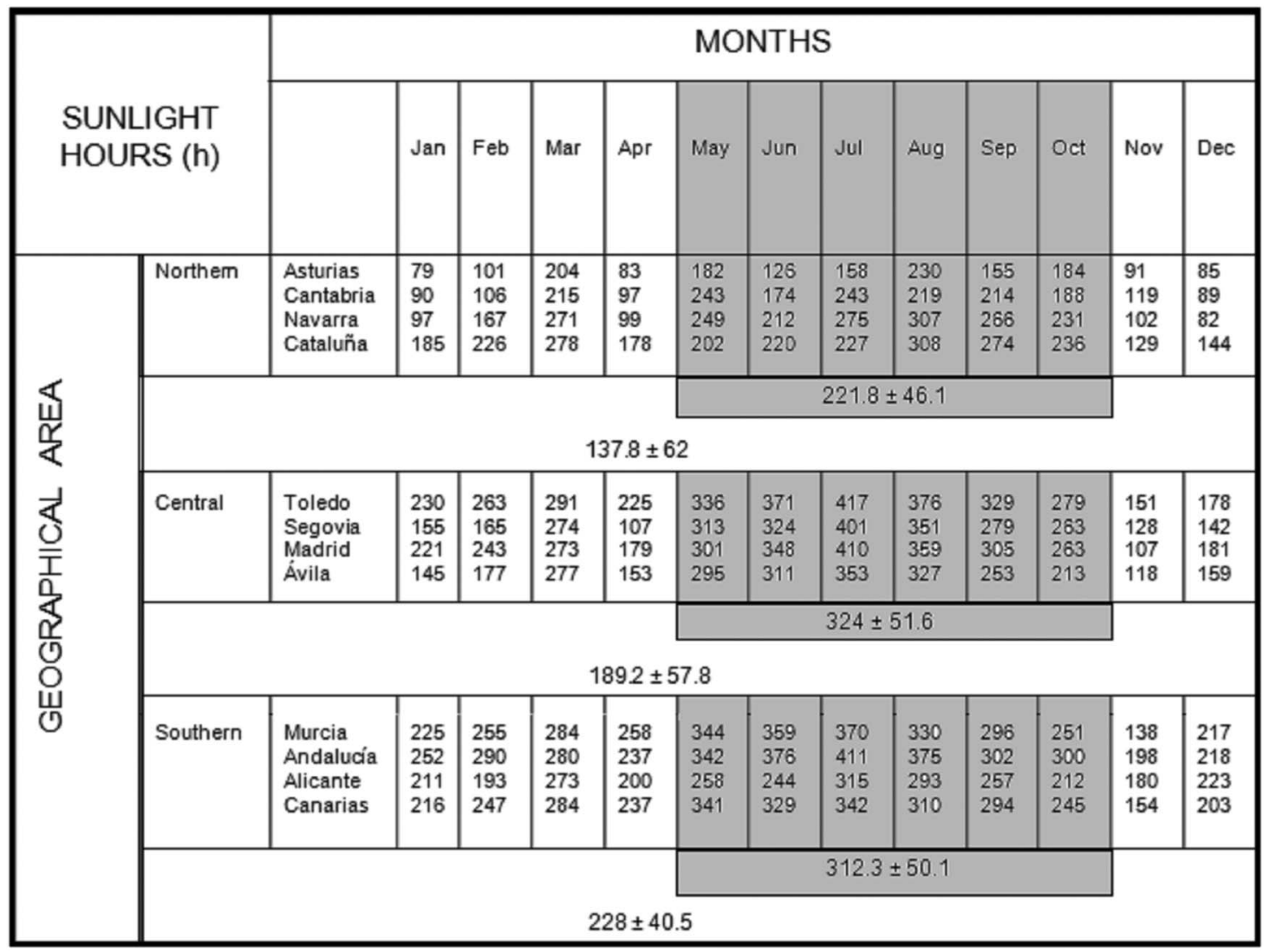

Figure 1 Number of hours of sunlight per month in 2012 according to geographical area (Northern, Central and Southern Spain). Data modified from original source available at: http://www.aemet.es/documentos_d/conocermas/biblioteca/calendarios/ cm-2013.pdf.

variables previously described as influencing viral response to treatment, there were no significant differences between the two groups.

In our cohort, $51.7 \%$ of patients were treated without lead-in therapy ( $n=8$, boceprevir; $n=473$, telaprevir) and $48.3 \%$ of patients with lead-in therapy $(n=310$, boceprevir; $n=64$, telaprevir; $n=75$, discontinued treatment after not achieving a decrease $1 \log$ RNA of baseline VL after 4 weeks of lead-in phase).

Among the patients that discontinued treatment after 4 weeks, 26 of 157 patients $(14.2 \%)$ initiated treatment during Season A and 49 of 217 (18.4\%) during Season B $(\mathrm{p}=0.240)$.

Patients were recruited from different geographical areas of Spain (figure 2), and the season of treatment initiation was equally distributed within regions, except for the Southern area (Northern area, $48.9 \%$ vs $51.1 \%$; Central area, $50.2 \%$ vs $49.8 \%$; Southern area, $61.8 \%$ vs $38.2 \%$, during Season A and Season B, respectively; $\mathrm{p}=0.003)$.

\section{Viral response to treatment and seasonality}

As expected, patients without lead-in therapy $(98 \%$ received peginterferon/ribavirin and telaprevir) achieved higher rates of RVR $(35.1 \%$ vs $2.7 \%, \mathrm{p} \leq 0.001)$ and $\mathrm{VL} \leq 15(79.2 \%$ vs $6.8 \%, \mathrm{p} \leq 0.001)$ compared with patients with lead-in therapy $(69 \%$ received peginterferon/ribavirin and boceprevir). Patients with RVR achieved a higher rate of SVR (131 of 155, 84.5\% vs 337 of 545, 61.8\%; $\leq \leq 0.001)$. Similarly, patients with VL $\leq 15$ also achieved a higher rate of SVR (280 of 338, $82.8 \%$ vs 185 of $355,52.1 \%$; $\leq 0.001)$.

Overall, patients initiating treatment during Season A showed higher rates of RVR $(23.5 \%$ vs $16.1 \%, \mathrm{p}=0.005)$ and $\mathrm{VL} \leq 15(51.0 \%$ vs $38.6 \%, \mathrm{p} \leq 0.001)$ than those initiating treatment during Season B. There were also differences between patients initiating treatment during Season $\mathrm{A}^{\prime}(\mathrm{n}=147)$ and patients treated during Season $\mathrm{B}^{\prime}$ $(\mathrm{n}=290) \quad(\mathrm{RVR}, 25.2 \%$ vs $18.3 \%, \mathrm{p}=0.104 ; \mathrm{VL} \leq 15,53.3 \%$ vs $38.2 \%, \mathrm{p}=0.004)$.

Analysis of viral response according to seasonality and type of treatment showed that patients treated during Season A with lead-in therapy exhibited a higher rate of viral response (RVR, 4.3 vs 1.5 in Season $B, p=0.07$; VL $\leq 15,10.4$ vs 4.2 in Season $\mathrm{B}, \mathrm{p}=0.013$; table 2). Seasonality in patients without lead-in therapy had less impact in viral response, although a trend was observed.

Table 3 shows the results of logistic regression analysis. Season of initiating treatment (Season A vs Season B) together with type of therapy (lead-in therapy, no vs yes), HCV RNA (low vs high VL) and IL-28 polymorphism (CC vs no $\mathrm{CC}$ ) proved to be independent predictors 
Table 1 Baseline characteristics of patients according to the season of initiating hepatitis $\mathrm{C}$ virus treatment

\begin{tabular}{|c|c|c|c|}
\hline & $\begin{array}{l}\text { Season } A \\
n=421\end{array}$ & $\begin{array}{l}\text { Season B } \\
n=509\end{array}$ & p Value \\
\hline Age (years) mean $\pm S D$ & $58.8 \pm 9.4$ & $54.4 \pm 8.3$ & 0.45 \\
\hline Age $>50$ years, $n(\%)$ & $261(62)$ & $333(65.4)$ & 0.30 \\
\hline Gender (male), n (\%) & $277(65.8)$ & $344(67.5)$ & 0.57 \\
\hline \multicolumn{4}{|l|}{ Body mass index* } \\
\hline$\leq 30 \mathrm{~kg} / \mathrm{m}^{2}$ & $119(78.8)$ & $143(79)$ & \multirow[t]{2}{*}{0.10} \\
\hline$>30 \mathrm{~kg} / \mathrm{m}^{2}$ & $32(21.2)$ & $38(21)$ & \\
\hline Diabetes mellitus, n (\%) & $65(12.8)$ & $65(15.4)$ & 0.25 \\
\hline \multicolumn{4}{|l|}{ HCV genotype } \\
\hline $1 \mathrm{a}, \mathrm{n}(\%)$ & $89(21.1)$ & $118(23.2)$ & \multirow[t]{3}{*}{0.68} \\
\hline $1 b, n(\%)$ & $283(67.2)$ & 347 (68.2) & \\
\hline Others, n (\%) & $49(11.6)$ & $44(8.6)$ & \\
\hline Low viral load (<600 000 UI), n (\%) & $109(26.2)$ & $111(21.9)$ & 0.14 \\
\hline Basal viral load IU, mean \pm SD & $2.459 .627 \pm 4.553 .883$ & $3.383 .240 \pm 5.406 .573$ & 0.006 \\
\hline Log RNA, mean $\pm S D$ & $6.06 \pm 0.60$ & $6.18 \pm 0.65$ & 0.007 \\
\hline \multicolumn{4}{|l|}{ Fibrosist } \\
\hline$\leq \mathrm{F} 2, \mathrm{n}(\%)$ & $67(12)$ & $66(13)$ & \multirow[t]{2}{*}{0.22} \\
\hline$\geq F 3-F 4, n(\%)$ & $351(84)$ & $438(87)$ & \\
\hline IL28B rs polymorphism CC, $\mathrm{n}(\%) \ddagger$ & 69 (49.3) & $71(50.7)$ & 0.29 \\
\hline \multicolumn{4}{|l|}{ Previous treatment } \\
\hline Naïve, n (\%) & $139(33)$ & $160(31)$ & \multirow[t]{8}{*}{0.62} \\
\hline Experienced, n (\%) & $282(67)$ & 349 (69) & \\
\hline No response & $45(16)$ & $70(20.1)$ & \\
\hline Early discontinuation & $13(4.6)$ & $17(4.9)$ & \\
\hline Unknown response & $47(16.7)$ & $83(23.8)$ & \\
\hline Relapse & $122(43.3)$ & $120(34.4)$ & \\
\hline Partial response & $50(17.7)$ & $48(13.8)$ & \\
\hline Breakthrough & $5(1.8)$ & $11(3.2)$ & \\
\hline AST, UI, mean \pm SD & $78 \pm 51$ & $82 \pm 54$ & 0.32 \\
\hline $\mathrm{ALT}, \mathrm{UI}, \mathrm{mean} \pm \mathrm{SD}$ & $99 \pm 67$ & $101 \pm 70$ & 0.76 \\
\hline GGT, UI, mean \pm SD & $109 \pm 96$ & $101 \pm 88$ & 0.19 \\
\hline
\end{tabular}

of RVR and VL $\leq 15$. No interaction between seasonality and INF lead-in therapy was found regarding RVR $(\mathrm{p}=0.145)$ and $\mathrm{VL} \leq 15(\mathrm{p}=0.300)$.

Furthermore, because the two treatments (lead-in vs no lead-in) differ in terms of efficacy, we performed a multivariate analysis of these groups separately, observing that the season of initiating treatment remained a predictor of RVR (table 4).

Viral response was not statistically different between patients initiating treatment in Season A compared with Season B assessed when VL was available at week 8 $(\mathrm{n}=262$ in Season $\mathrm{A}, \mathrm{n}=341$ in Season $\mathrm{B} ; \mathrm{VL} \leq 15,43.8 \%$ vs $56.2 \%, \mathrm{p}=0.703)$, week $12(\mathrm{n}=395$ in Season $\mathrm{A}, \mathrm{n}=465$ in Season B; VL $\leq 15,45.9 \%$ vs $54.1 \%, \mathrm{p}=0.923$ ), end of treatment $(n=163$ in Season A, $n=200$ in Season B; HCV RNA undetectable, $46 \%$ vs $54 \%, \mathrm{p}=0.437)$ and SVR $(\mathrm{n}=328$ in Season $\mathrm{A}, \mathrm{n}=372$ in Season B; HCV RNA undetectable, $48.1 \%$ vs $51.9 \%, \mathrm{p}=0.358)$.

Baseline VL was significantly different between the two periods considered. Nonetheless, this difference was clinically irrelevant and was adjusted for in the multivariate analysis. Analysis was performed considering baseline VL as categorical and continuous variable (quantitative RNA, online supplementary table S1), finding that seasonality remained as an independent predictor variable.

Since relapsers do have a different response to retreatment more like naive patients, a subanalysis was performed considering both group of patients together compared with the others. Seasonality remained an independent predictor (see online supplementary table S2).

\section{Vitamin D levels and seasonality}

As shown in figure 3, vitamin D levels in our small sample oscillated according to season, but were not significantly different between patients initiating treatment in Season A compared with Season B (49.2 \pm 23.4 vs 47.8 $\pm 20.7 \mathrm{nmol} / \mathrm{L}, \mathrm{p}=828, \mathrm{n}=115$ ).

\section{DISCUSSION}

This is the first study to establish a link between the season of initiating interferon/ribavirin-based therapy 
Figure 2 Schematic representation of patients included in the study according to geographical area. Grey crosses represent patients starting treatment during Season A (May-October) and red circles represent patients starting treatment during Season B (November-April).

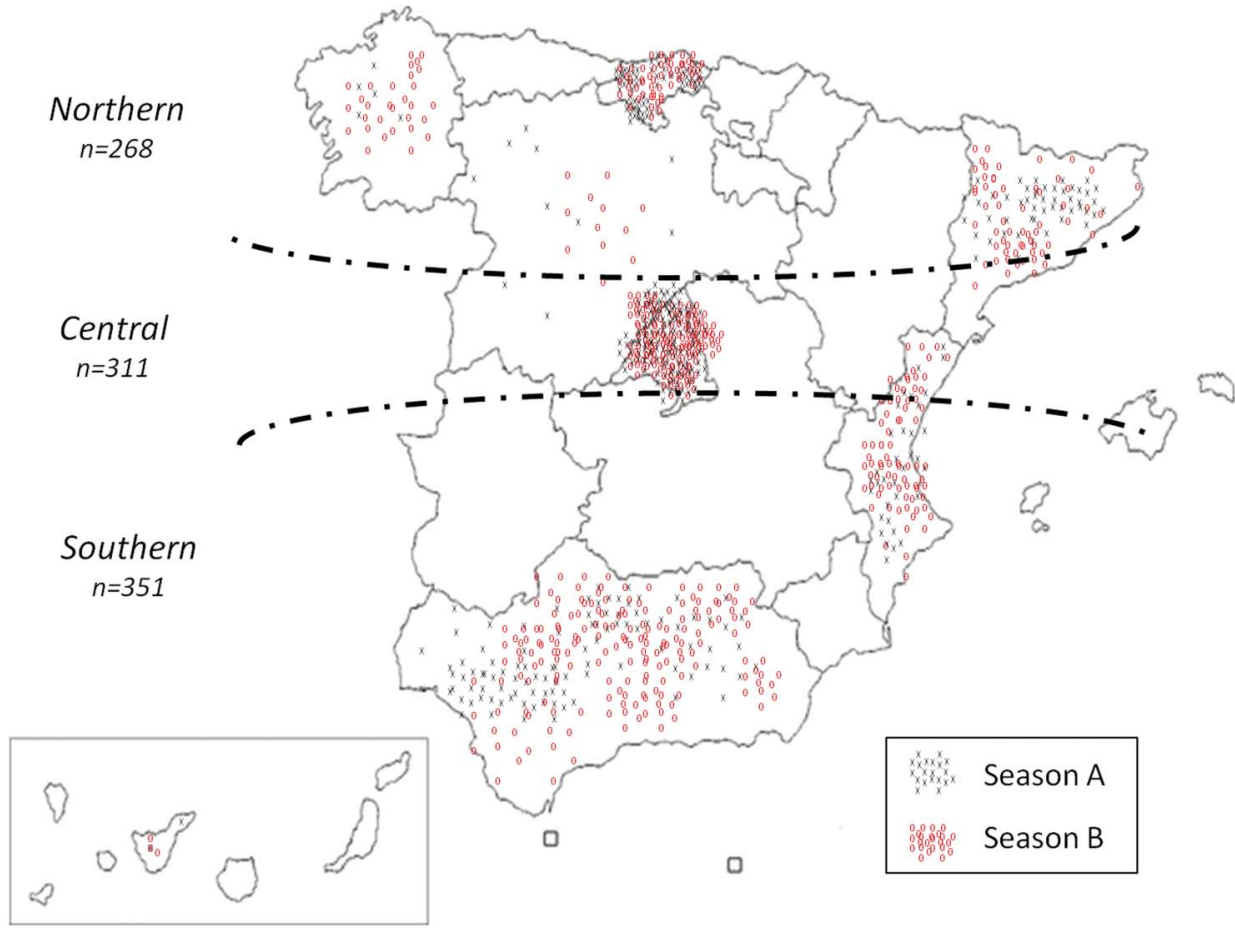

Table 2 Viral response according to lead-in therapy with interferon and season of initiating hepatitis C virus treatment

\begin{tabular}{|c|c|c|c|c|c|c|}
\hline & $\begin{array}{l}\text { Without lead-in } \\
\text { Season A }\end{array}$ & Season B & p Value & $\begin{array}{l}\text { Lead-in } \\
\text { Season A }\end{array}$ & Season B & p Value \\
\hline Rapid viral response, n (\%) & $91(38.2)$ & $78(32)$ & 0.18 & $8(4.3)$ & $4(1.5)$ & 0.07 \\
\hline RNA undetectable or VL $\leq 15$ UI at 4 weeks, $n(\%)$ & $193(82.5)$ & $181(76)$ & 0.09 & $19(10.4)$ & $11(4.2)$ & 0.013 \\
\hline Viral response at 8 weeks, $\mathrm{n}(\%)$ & $79(64)$ & $85(58.2)$ & 0.38 & $60(44.1)$ & $87(44.6)$ & 0.99 \\
\hline $\mathrm{VL} \leq 15 \mathrm{Ul}$ at 8 weeks, $\mathrm{n}(\%)$ & $119(97)$ & $137(94)$ & 0.39 & $95(70)$ & $136(70)$ & 0.99 \\
\hline Viral response at 12 weeks, $\mathrm{n}(\%)$ & $151(66.6)$ & $145(62)$ & 0.83 & $94(56.3)$ & $126(54)$ & 0.74 \\
\hline VL $\leq 15$ Ul at 12 weeks, $n(\%)$ & $215(94)$ & $213(91.4)$ & 0.48 & $135(81)$ & $200(85.5)$ & 0.86 \\
\hline Sustained viral response, $\mathrm{n}(\%)$ & $147(74.2)$ & $147(72)$ & 0.57 & $78(60)$ & $96(57.5)$ & 0.72 \\
\hline
\end{tabular}

for CHC and viral response to treatment. Our results suggest that viral response to treatment was influenced by the hours of sunlight, and by inference, sunlight exposure, a surrogate marker of vitamin D levels.

The most striking finding in our cohort of patients from different latitudes was that a different viral response was observed according to the season of initiating peginterferon/ribavirin-based treatment. In fact, patients starting treatment during the season with the highest daily hours of sunlight, according to the State Meterological Agency, ${ }^{17}$ showed the highest rate of RVR. We believe our findings are coherent for different reasons. First, the rate of viral response correlated well with the effectiveness of treatment since the largest difference in the response pattern was observed in patients receiving lead-in therapy instead of direct-acting antiviral agents from the outset. Second, multivariate analysis adjusted for variables influencing viral response clearly revealed that seasonality was an independent predictor for viral response. This was observed no matter what VL cut-off value was considered, either undetectable, $\leq 15$ UI or both. In addition, other variables previously shown to influence RVR such as baseline VL $>600000 \mathrm{IU} / \mathrm{mL}$ and IL-28B gene polymorphism, ${ }^{11} 1819$ also appeared to be independent factors in our cohort of patients. Finally, our subanalysis of peak months regarding sunlight exposure confirmed the results, albeit with a smaller sample size, and reinforces the overall results.

Our data are of considerable importance as RVR is highly correlated with SVR in peginterferon/ribavirinbased regimens. ${ }^{152021}$ In fact, in our cohort of patients, RVR was associated with SVR. In addition, our results can be considered as proof of concept that vitamin D levels may influence response to treatment for HCV.

Although the regimens used in this study are not those recommended in current clinical practice, it is important to note that, in some countries of Eastern Europe, Asia, the Middle East and South America, with a high prevalence of HCV, DAA regimens without 
Table 3 Multivariate logistic analysis

\begin{tabular}{|c|c|c|c|c|c|c|}
\hline & \multicolumn{3}{|c|}{ Rapid viral response } & \multicolumn{3}{|c|}{ Undetectable or VL $\leq 15 \mathrm{UI}$} \\
\hline & $\overline{\text { OR }}$ & $95 \% \mathrm{Cl}$ & p Value & $\overline{\text { OR }}$ & $95 \% \mathrm{Cl}$ & p Value \\
\hline Treatment initiation (Season A vs Season B) & 2.03 & 1.27 to 3.25 & 0.003 & 1.93 & 1.14 to 3.29 & 0.014 \\
\hline Type of therapy (lead-in no vs yes) & 23.70 & 10.66 to 52.69 & $<0.0001$ & 90.1 & 46.54 to 174.6 & $<0.0001$ \\
\hline HCV RNA ( $\leq 600000$ vs >600 $000 \mathrm{IU} / \mathrm{mL})$ & 2.14 & 1.29 to 3.55 & 0.003 & 4.66 & 2.36 to 9.17 & $<0.0001$ \\
\hline IL-28 polymorphism (CC vs no CC) & 1.94 & 1.14 to 3.30 & 0.014 & 2.24 & 1.17 to 4.29 & 0.015 \\
\hline Naïve vs experienced & 1.55 & 0.91 to 2.63 & 0.10 & 0.74 & 0.41 to 1.31 & 0.30 \\
\hline Genotype (1b vs 1a) & 1.32 & 0.73 to 2.40 & 0.35 & 0.71 & 0.37 to 1.36 & 0.30 \\
\hline Diabetes mellitus (no vs yes) & 1.28 & 0.63 to 2.61 & 0.49 & 1.42 & 0.66 to 3.05 & 0.36 \\
\hline Age ( $\geq 50$ vs $<50$ years) & 0.92 & 0.55 to 1.52 & 0.75 & 1.01 & 0.58 to 1.78 & 0.95 \\
\hline Fibrosis ( $\geq \mathrm{F} 3$ vs < $<3$ ) & 0.92 & 0.51 to 1.66 & 0.79 & 1.63 & 0.80 to 3.30 & 0.17 \\
\hline
\end{tabular}

Table 4 Multivariate logistic analysis grouped by type of therapy

\begin{tabular}{|c|c|c|c|c|c|c|}
\hline \multirow[b]{2}{*}{ Type of therapy } & \multicolumn{2}{|c|}{ Rapid viral response } & \multirow{2}{*}{$\begin{array}{l}\text { Lead-in } \\
\text { p Value }\end{array}$} & \multicolumn{2}{|c|}{ Undetectable or VL $\leq 15 \mathrm{UI}$} & \multirow[b]{2}{*}{ p Value } \\
\hline & OR & $95 \% \mathrm{Cl}$ & & OR & $95 \% \mathrm{Cl}$ & \\
\hline Treatment initiation (Season A vs Season B & 43.31 & 1.88 to 996.65 & 0.019 & 3.36 & 1.10 to 10.16 & 0.031 \\
\hline HCV RNA ( $\leq 600000$ vs >600 $000 \mathrm{IU} / \mathrm{mL}$ ) & 23.95 & 2.75 to 208.41 & 0.004 & 8.86 & 3.02 to 25.94 & $<0.001$ \\
\hline IL-28 polymorphism (CC vs no CC) & 7.29 & 0.94 to 56.17 & 0.056 & 4.00 & 1.34 to 11.94 & 0.013 \\
\hline Naïve vs experienced & 5.68 & 0.591 to 54.56 & 0.132 & 1.02 & 0.37 to 2.86 & 0.959 \\
\hline Genotype (1b vs 1a) & 0.18 & 0.02 to 1.62 & 0.128 & 0.55 & 0.17 to 1.799 & 0.328 \\
\hline Diabetes mellitus (no vs yes) & 0.27 & 0.02 to 3.62 & 0.326 & 0.98 & 0.19 to 0.87 & 0.985 \\
\hline Age ( $\geq 50$ vs $<50$ years) & 2.78 & 0.44 to 17.65 & 0.276 & 1.38 & 0.48 to 3.97 & 0.542 \\
\hline \multirow[t]{2}{*}{ Fibrosis ( $\geq \mathrm{F} 3$ vs $<\mathrm{F} 3$ ) } & 3.69 & 0.22 to 62.58 & 0.365 & 0.98 & 0.17 to 5.63 & 0.987 \\
\hline & \multicolumn{2}{|c|}{ Rapid viral response } & Without lead-in & \multicolumn{2}{|c|}{ Undetectable or VL $\leq 15 \mathrm{UI}$} & \\
\hline Type of therapy & $\overline{\text { OR }}$ & $95 \% \mathrm{CI}$ & p Value & OR & $95 \% \mathrm{Cl}$ & p Value \\
\hline Treatment initiation (Season A vs Season B & 1.78 & 1.93 to 2.90 & 0.021 & 1.61 & 0.86 to 3.01 & 0.131 \\
\hline HCV RNA ( $\leq 600000$ vs >600 $000 \mathrm{lU} / \mathrm{mL})$ & 1.76 & 1.04 to 3.00 & 0.035 & 3.11 & 1.32 to 7.30 & 0.009 \\
\hline IL-28 polymorphism (CC vs no CC) & 1.81 & 1.03 to 3.16 & 0.037 & 1.84 & 0.83 to 4.08 & 0.132 \\
\hline Naïve vs experienced & 1.51 & 0.87 to 2.63 & 0.138 & 0.66 & 0.32 to 1.36 & 0.267 \\
\hline Genotype (1b vs 1a) & 1.52 & 0.81 to 2.84 & 0.191 & 0.74 & 0.33 to 1.64 & 0.468 \\
\hline Diabetes mellitus (no vs yes) & 1.36 & 0.64 to 2.85 & 0.416 & 1.57 & 0.67 to 3.67 & 0.296 \\
\hline Age ( $\geq 50$ vs $<50$ years) & 0.83 & 0.49 to 1.40 & 0.488 & 0.87 & 0.44 to 1.69 & 0.684 \\
\hline Fibrosis ( $\geq \mathrm{F} 3$ vs $<\mathrm{F} 3$ ) & 0.88 & 0.48 to 1.60 & 0.681 & 1.89 & 0.82 to 4.38 & 0.133 \\
\hline
\end{tabular}

peginterferon have not been implemented as the only therapeutic regimen, and treatments that include peginterferon and ribavirin are still present. ${ }^{22-24}$

Since the first observation published in 2010 about low vitamin $\mathrm{D}$ serum level being related to poor response to peginterferon/ribavirin-based therapy in genotype $1 \mathrm{CHC}^{3}{ }^{3}$ several studies have supported the association of vitamin $\mathrm{D}$ and viral response to treatment, ${ }^{25} 26$ attributing the rate of early virological response to the role of vitamin $\mathrm{D}$ in regulating the immune response. In recent years, there has been increasing interest in the role of vitamin $\mathrm{D}$, in terms of bone homeostasis as well as in different tissues and its relationship with non-skeletal effects. ${ }^{1}{ }^{2}$ Vitamin D plays an important role in the immune system and some immune cells possess vitamin $\mathrm{D}$ receptors, suggesting a regulatory role for vitamin $\mathrm{D}$ in innate and adaptive immune responses. ${ }^{27} 28$
Several studies have shown that vitamin D supplementation significantly improves the rate of RVR, early viral response and SVR. ${ }^{29-33}$ In contrast, other studies have not confirmed better outcomes of antiviral therapy after vitamin D supplementation ${ }^{33} 34$ or any correlation between vitamin $\mathrm{D}$ levels and viral response. ${ }^{35}$ However, methodological bias regarding serum vitamin D measurement has been noted, such as differences in circulating vitamin $\mathrm{D}$ binding protein, ${ }^{36}$ the absence of an optimal and clinically relevant vitamin D level cut-off value $^{37}$ or the accuracy of vitamin D assays. ${ }^{38}$ These and other difficulties may theoretically preclude the possibility of finding any correlation trend even if it were present.

In addition, the benefits of supplementation may go beyond hepatitis $\mathrm{C}$ treatment response. In this regard, higher vitamin $\mathrm{D}$ levels have been associated with less inflammation and liver fibrosis in HCV patients. ${ }^{3} 7$ 

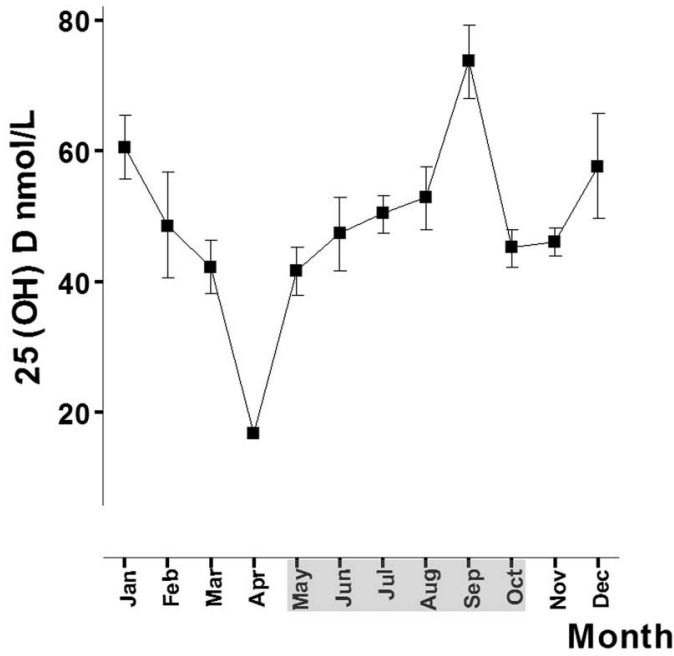

Figure 3 Seasonal variation of vitamin D. Vitamin D levels oscillated during the year depending on the season. The months of Season A (May-October) are shaded in grey.

Indeed, adequate levels of vitamin $\mathrm{D}$ reduce oxidative stress, influence the migration, proliferation and gene expression of fibroblasts as well as reduce the fibrogenic activity of liver stellate cells. ${ }^{3}$ Additionally, a recent study supports the notion that supplementation with vitamin $\mathrm{D}$ in peginterferon/ribavirin-based regimen significantly improves viral response and helps to prevent other problems like the risk of emerging bone fragility in children. ${ }^{32}$ Vitamin D may also reduce anaemia induced by ribavirin. ${ }^{9}$ Finally, a recent meta-analysis of randomised controlled trials has suggested a reduction in all-cause mortality with vitamin D supplementation. ${ }^{39}$

Several studies have demonstrated that seasonal changes and ultraviolet light exposure correlate with vitamin D levels, as sunlight is the main source of vitamin $\mathrm{D}$, especially in sunny countries such as Spain. ${ }^{40-42}$ Not surprisingly, in our study, a consistent association was observed between vitamin D levels and seasonal variation, although vitamin D levels were only available in a minority of our large cohort of patients. In addition, several studies have suggested decreased risks and severity of autoimmune, endocrine, cardiovascular and oncology diseases after moderate exposure to ultraviolet radiation. Thus, it is reasonable to assume a correlation between vitamin D levels and sunlight exposure. ${ }^{43-45}$ Conversely, increased severity and prolonged hospitalisation rates have been associated with low sunlight exposure in patients with inflammatory bowel diseases ${ }^{46}$ or sepsis. ${ }^{47}$

There were no differences in baseline characteristics between patients grouped according to season. However, baseline VL was significantly different between the two periods considered. Although the difference was clinically irrelevant and was adjusted for in the multivariate analysis, the finding deserves a comment. It is tempting to speculate that longer hours of sunlight may have anti-HCV effects, targeting the assembly of the infectious virus and reducing intracellular and extracellular infectivity titres, since vitamin $\mathrm{D}$ has shown to play a role as a natural antiviral mediator. ${ }^{8}{ }^{4-51}$ It is important to note that an inverse relationship between vitamin $\mathrm{D}$ levels and VL in hepatitis B has also been reported. ${ }^{52} 53$

Although we did observe an association between seasonality and RVR, when later time points were assessed including SVR, no such relationship was found. This is not surprising since direct-acting NS3 protease inhibitors are very effective drugs and other well-known predictors of SVR also fail to have predictive value. ${ }^{35} 54-56$ Similarly, no association between vitamin D levels and SVR has been found in easy-to-treat patients such as those with HCV genotype 2 and $3 .^{7}$

To the best of our knowledge, this is the first epidemiological study to compare two groups of HCV patients treated in different periods of the year. Previously, attempts have been made to compare cure rates between different countries in different latitudes, but it is difficult to draw valid and reliable conclusions from them due to the influence of inherent differences such as race, genetic factors, etc, which are difficult to control. ${ }^{7}$

Our study has certain limitations. First, there is a lack of data on drugs that interfere with vitamin D levels, supplements or dietary intake. Also, data about mutation CYP27B $1,{ }^{29}$ which has been found to affect vitamin D levels, were not available. Finally, individual sunlight exposure was not available and patients were therefore grouped according to seasons established according to ultraviolet meteo-geographic statistics.

Although peginterferon and ribavirin have been displaced by new DAAs and their use is increasingly limited in the treatment of hepatitis $\mathrm{C}$, we should not forget that interferon is still used to treat hepatitis B and is the only existing therapy for hepatitis D. So the present study opens the possibility of exploring the effect of daylight hours on initiation of treatment and, by inference, vitamin D metabolism, which is poorly studied. ${ }^{57-59}$

In conclusion, seasonality in our setting had an impact on viral kinetics in HCV genotype 1 patients treated with peginterferon/ribavirin-based therapy. Our findings provide further support for the hypothesis that vitamin D influences viral response to treatment.

Acknowledgements The authors thank Cristina Fuentes and Angel Estébanez for technical assistance, Alejandro Jimenez for statistical support and CIBICAN for editorial support.

Collaborators Sabela Lens García; Jose Luis Montero Álvarez; Ángela Rojas Álvarez-Ossorio; Javier García-Samaniego; María Buti; Juan Turnes; J Javier Moreno Palomares; Mónica González García; Beatriz Álvarez Suárez; Carlos Fernández-Carrillo.

Funding This research received no specific grant from any funding agency in the public, commercial or not-for-profit sectors.

Competing interests None declared.

\section{Patient consent Obtained.}

Ethics approval Approval for the study protocol was obtained from the promoter's research ethics committee and written informed consent was obtained from all participants. The study was conducted in accordance with the principles of the 1975 Declaration of Helsinki. 
Provenance and peer review Not commissioned; externally peer reviewed.

Data sharing statement No additional data are available.

Open Access This is an Open Access article distributed in accordance with the Creative Commons Attribution Non Commercial (CC BY-NC 4.0) license, which permits others to distribute, remix, adapt, build upon this work noncommercially, and license their derivative works on different terms, provided the original work is properly cited and the use is non-commercial. See: http:// creativecommons.org/licenses/by-nc/4.0/

\section{REFERENCES}

1. Kitson MT, Roberts SK. D-livering the message: the importance of vitamin D status in chronic liver disease. J Hepatol 2012;57:897909.

2. Rosen CJ, Adams JS, Bikle DD, et al. The nonskeletal effects of vitamin D: an Endocrine Society scientific statement. Endocr Rev 2012;33:456-92.

3. Petta $\mathrm{S}$, Cammà $\mathrm{C}$, Scazzone $\mathrm{C}$, et al. Low vitamin $\mathrm{D}$ serum level is related to severe fibrosis and low responsiveness to interferon-based therapy in genotype 1 chronic hepatitis C. Hepatology 2010;51:1158-67.

4. Arteh J, Narra S, Nair S. Prevalence of vitamin D deficiency in chronic liver disease. Dig Dis Sci 2010;55:2624-8.

5. Lim LY, Chalasani N. Vitamin d deficiency in patients with chronic liver disease and cirrhosis. Curr Gastroenterol Rep 2012;14:67-73.

6. Iruzubieta P, Terán Á, Crespo J, et al. Vitamin D deficiency in chronic liver disease. World J Hepatol 2014;6:901-15.

7. García-Álvarez M, Pineda-Tenor D, Jiménez-Sousa MA, et al. Relationship of vitamin $D$ status with advanced liver fibrosis and response to hepatitis $\mathrm{C}$ virus therapy: a meta-analysis. Hepatology 2014;60:1541-50.

8. Gal-Tanamy M, Bachmetov L, Ravid A, et al. Vitamin D: an innate antiviral agent suppressing hepatitis $C$ virus in human hepatocytes. Hepatology 2011;54:1570-9.

9. Refaat B, Ashour TH, El-Shemi AG. Ribavirin induced anaemia: the effect of vitamin $D$ supplementation on erythropoietin and erythrocyte indices in normal Wistar rat. Int $J$ Clin Exp Med 2014:15:2667-76.

10. Omori-Mizuno $\mathrm{Y}$, Nakayama $\mathrm{N}$, Inao $\mathrm{M}$, et al. Randomized study comparing vitamin D3 and 1 $\alpha$-hydroxyvitamin D3 in combination with pegylated interferon/ribavirin therapy for chronic hepatitis $C$. $J$ Gastroenterol Hepatol 2015;30:1384-90.

11. Petta S, Ferraro D, Cammà C, et al. Vitamin D levels and IL28B polymorphisms are related to rapid virological response to standard of care in genotype 1 chronic hepatitis C. Antivir Ther 2012;17:823-31.

12. Lange CM, Bibert S, Kutalik Z, et al. A genetic validation study reveals a role of vitamin $D$ metabolism in the response to interferon-alfa-based therapy of chronic hepatitis C. PLOS ONE 2012;7:e40159.

13. Villar LM, Del Campo JA, Ranchal I, et al. Association between vitamin $\mathrm{D}$ and hepatitis $\mathrm{C}$ virus infection: a meta-analysis. World $J$ Gastroenterol 2013;19:5917-24

14. Lerias de Almeida PR, Alves de Mattos, Valle Tovo C. Sustained virological response according to the type of early virological response in HCV and HCV/HIV. Ann Hepatol 2010;9:150-5.

15. Federico $A$, Masarone $M$, Romano $M$, et al. Rapid virological response represents the highest prediction factor of response to antiviral treatment in HCV-related chronic hepatitis: a multicenter retrospective study. Hepat Mon 2015;15:e18640.

16. Wacker M, Holick MF. Sunlight and vitamin D: a global perspective for health. Dermatoendocrinology 2013;5:51-108.

17. Agencia Estatal de Meteorología (AEMET). Calendario Meteorológico del 2013. http:www.aemet.es/documentos_d/ conocermas/biblioteca/calendarios/cm-2013.pdf

18. Zeuzem S, Buti M, Ferenci $\mathrm{P}$, et al. Efficacy of 24 weeks treatment with peginterferon alfa-2b plus ribavirin in patients with chronic hepatitis $\mathrm{C}$ infected with genotype 1 and low pretreatment viremia. $J$ Hepatol 2006;44:97-103.

19. Jensen DM, Morgan TR, Marcellin $\mathrm{P}$, et al. Early identification of HCV genotype 1 patients responding to 24 weeks peginterferon alpha-2a (40 kd)/ribavirin therapy. Hepatology 2006;43:954-60.

20. Shea DO, Tuite $\mathrm{H}$, Farrell $\mathrm{G}$, et al. Role of rapid virological response in prediction of sustained virological response to Peg-IFN plus ribavirin in HCV / HIV co-infected individuals. J Viral Hepat 2008;15:482-9.

21. Yu JW, Wang GQ, Sun LJ, et al. Predictive value of rapid virological response and early virological response on sustained virological response in HCV patients treated with pegylated interferon alpha-2a and ribavirin. J Gastroenterol Hepatol 2007;22:832-6.

22. Luhmann N, Champagnat J, Golovin S, et al. Access to hepatitis C treatment for people who inject drugs in low and middle income settings: evidence from 5 countries in Eastern Europe and Asia. Int J Drug Policy 2015;26:1081-7.

23. Wei L, Lok AS. Impact of new hepatitis C treatments in different regions of the world. Gastroenterology 2014;146:1145-50.

24. European Association for Study of Liver. EASL recommendations on treatment of hepatitis C 2015. J Hepatol 2015;63:199-236.

25. Ladero JM, Torrejón MJ, Sánchez-Pobre $P$, et al. Vitamin $D$ deficiency and vitamin D therapy in chronic hepatitis C. Ann Hepato 2013;12:199-204.

26. Falleti E, Cmet S, Fabris C, et al. Genetic polymorphisms of vitamin $\mathrm{D}$ pathway predict antiviral treatment outcome in slow responder naïve patients with chronic hepatitis C. PLOS ONE 2013;8:e80764.

27. Kikuta J, Ishii M. [Current Topics on Vitamin D. The effects of vitamin D on the immune system]. Clin Calcium 2015;25:359-65.

28. Chun RF, Liu PT, Modlin RL, et al. Impact of vitamin D on immune function: lessons learned from genome-wide analysis. Front Physiol 2014;151:1-15.

29. Abu-Mouch S, Fireman Z, Jarchovsky J, et al. Vitamin D supplementation improves sustained virologic response in chronic hepatitis C (genotype 1)-naïve patients. World J Gastroenterol 2011;17:5184-90.

30. Nimer A, Mouch A. Vitamin D improves viral response in hepatitis $C$ genotype $2-3$ naïve patients. World J Gastroenterol 2012;18:800-5

31. Yokoyama S, Takahashi S, Kawakami Y, et al. Effect of vitamin D supplementation on pegylated interferon/ribavirin therapy for chronic hepatitis $\mathrm{C}$ genotype $1 \mathrm{~b}$ : a randomized controlled trial. J Viral Hepat 2014;21:348-56.

32. Eltayeb AA, Abdou MA, Abdel-aal AM, et al. Vitamin D status and viral response to therapy in hepatitis $\mathrm{C}$ infected children. World $J$ Gastroenterol 2015;21:1284-91.

33. Kitson MT, Sarrazin C, Toniutto $P$, et al. Vitamin D level and sustained virologic response to interferon-based antiviral therapy in chronic hepatitis C: a systematic review and meta-analysis. $J$ Hepatol 2014:61:1247-52.

34. Esmat G, El Raziky M, Elsharkawy A, et al. Impact of vitamin D supplementation on sustained virological response in chronic hepatitis $\mathrm{C}$ genotype 4 patients treated by pegylated interferon/ ribavirin. J Interferon Cytokine Res 2015;35:49-54.

35. Grammatikos G, Lange C, Susser S, et al. Vitamin D levels vary during antiviral treatment but are unable to predict treatment outcome in HCV genotype 1 infected patients. PLOS ONE 2014;9: e87974

36. Nimitphong $\mathrm{H}$, Saetung $\mathrm{S}$, Chanprasertyotin $\mathrm{S}$, et al. Changes in circulating 25-hydroxyvitamin D according to vitamin D binding protein genotypes after vitamin $D_{3}$ or $D_{2}$ supplementation. Nutr $J$ 2013;12:39.

37. Bischoff-Ferrari HA. Optimal serum 25-hydroxyvitamin D levels for multiple health outcomes. Adv Exp Med Biol 2014;810:500-25.

38. Carter GD. Accuracy of 25-hydroxyvitamin D assays: confronting the issues. Curr Drug Targets 2011;12:19-28.

39. Zheng Y, Zhu J, Zhou M, et al. Meta-analysis of long-term vitamin D supplementation on overall mortality. PLOS ONE 2013;8:e82109.

40. Rosen CJ. Clinical practice. Vitamin D insufficiency. N Engl J Med $2011 ; 364: 248-54$

41. Kasahara AK, Singh RJ, Noymer A. Vitamin D (25OHD) serum seasonality in the United States. PLOS ONE 2013;8:e65785.

42. Andersen R, Brot C, Jakobsen J, et al. Seasonal changes in vitamin $\mathrm{D}$ status among Danish adolescent girls and elderly women: the influence of sun exposure and vitamin D intake. Eur J Clin Nutr 2013;67:270-4.

43. Kriegel MA, Manson JE, Costenbader KH. Does vitamin D affect risk of developing autoimmune disease?: a systematic review. Semin Arthritis Rheum 2011:40:512-31.

44. Hossein-nezhad A, Holick MF. Vitamin D for health: a global perspective. Mayo Clin Proc 2013;88:720-55

45. Grant WB, Wimalawansa SJ, Holick MF, et al. Emphasizing the health benefits of vitamin $D$ for those with neurodevelopmental disorders and intellectual disabilities. Nutrients 2015;7:1538-64.

46. Limketkai BN, Bayless TM, Brant SR, et al. Lower regional and temporal ultraviolet exposure is associated with increased rates and severity of inflammatory bowel disease hospitalisation. Aliment Pharmacol Ther 2014;40:508-17.

47. Danai PA, Sinha S, Moss M, et al. Seasonal variation in the epidemiology of sepsis. Crit Care Med 2007;35:410-5.

48. Matsumura T, Kato T, Sugiyama N, et al. 25-Hydroxyvitamin D3 suppresses hepatitis C virus production. Hepatology 2012;56:1231-9. 
49. Yuk JM, Shin DM, Lee HM, et al. Vitamin D3 induces autophagy in human monocytes/macrophages via cathelicidin. Cell Host Microbe 2009;6:231-43.

50. Spector SA. Vitamin D and HIV: letting the Sun shine in. Top Antivir Med 2011;19:6-10.

51. Martineau AR, Timms PM, Bothamley GH, et al. High-dose vitamin $\mathrm{D}(3)$ during intensive-phase antimicrobial treatment of pulmonary tuberculosis: a double-blind randomised controlled trial. Lancet 2011;377:242-50.

52. Farnik H, Bojunga J, Berger A, et al. Low vitamin D serum concentration is associated with high levels of hepatitis $B$ virus replication in chronically infected patients. Hepatology 2013;58:1270-6.

53. Chan $\mathrm{HL}$, Elkhashab $\mathrm{M}$, Trinh $\mathrm{H}$, et al. Association of baseline vitamin $D$ levels with clinical parameters and treatment outcomes in chronic hepatitis B. J Hepatol 2015;63: 1086-92.
54. Petta S, Craxì A. How to optimize HCV therapy in genotype 1 patients: predictors of response. Liver Int 2013;33(Suppl 1):23-9.

55. Poordad F, Bronowicki JP, Gordon SC, et al. Factors that predict response of patients with hepatitis $\mathrm{C}$ virus infection to boceprevir. Gastroenterology 2012;143:608-18.

56. Shimada N, Toyoda H, Tsubota A, et al. Baseline factors and very early viral response (week 1) for predicting sustained virological response in telaprevir-based triple combination therapy for Japanese genotype $1 \mathrm{~b}$ chronic hepatitis $\mathrm{C}$ patients: a multicenter study. $J$ Gastroenterol 2014;49:1485-94.

57. Liu J, Yang HI, Lee MH, et al. Incidence and determinants of spontaneous hepatitis B surface antigen seroclearance: a community-based follow-up study. Gastroenterology 2010;139:474-82.

58. Abbas Z, Memon MS, Umer MA, et al. Co-treatment with pegylated interferon alfa-2a and entecavir for hepatitis $\mathrm{D}$ : a randomized trial. World J Hepatol 2016;8:625-31.

59. Rizzetto M. The adventure of delta. Liver Int 2016;36(Suppl 1):135-40. 